\title{
The spatial peculiarities of economic and social convergence in Central and Eastern Europe
}

Zoltán Egri This study examines the convergence and catch-

Szent István University,

Hungary

E-mail: egri.zoltan@gk.szie.hu

Tamás Tánczos

Eszterházy Károly University,

Hungary

E-mail: tanczos.tamas@uni-

eszterhazy.hu

Keywords:

convergence,

catch-up effect, economic performance,

well-being,

spatial econometrics up effects of the economic and social (well-being) performance of the NUTS 2 regions of Central and Eastern Europe between 2004 and 2014. The separate management of these two development dimensions is justified by the fact that they have no clear relationship. In the study, the theory of closed economies is abandoned and, thus, the performed regression analyses include spatial interactions and spillover effects. As the applied regressions provide only an average picture about the studied phenomenon, the authors also present the individual paths for each region.

The results confirm the theory of absolute convergence for both the economic and social convergence. Thus, regardless of any other explanatory factor, less developed regions tend to converge with the more developed ones. The traditional examinations and those that assess spatiality aspects point to a faster annual convergence rate of well-being, so the two phenomena have different dynamics. This is partly supported by the individual regional catch-up paths. Furthermore, it clearly complements the mathematicalstatistical results. The novel results highlight the catching up of the 'local dimension' that puts the regions along the two dimensions as 'catch-up not complete' and 'catch-up complete'. The authors' results suggest a non-parallel way of achieving social and economic cohesion.

\section{Introduction}

Our study discusses the spatial peculiarities or chances of convergence in Central and Eastern Europe in the European Union (EU). Convergence and equalisation between regions strongly affects, and is clearly associated with, the main political

Regional Statistics, Vol. 8. No. 1. 2018: 49-77; DOI: 10.15196/RS080108 
goals of the EU. Article 130a of the Treaty of Rome (1957) clearly states that 'In order to promote its overall harmonious development, the Community shall develop and pursue its actions leading to the strengthening of its economic and social cohesion. In particular, the Community shall aim at reducing disparities between the levels of development of various regions and the backwardness of the leastfavoured regions...' This statement was confirmed later in the Single European Act (1987). Then, in 2012, the Treaty of the European Union added a new (territorial) attribute to the existing economic and social attributes, highlighting the importance of territorial convergence.

The different interpretations of convergence are, at least partly, evident from the following. On the one hand, it is considered a set of efforts to reach a reference point and, on the other hand, it is a set of attempts for approximation and to reduce inequalities (Ferkelt-Gáspár 2008, Oblath-Szörfi 2008). Kotosz and Lengyel (2017) and Paas et al. (2007) use three categories to characterise convergence processes. In the absolute convergence hypothesis, less developed regions tend to converge with more developed ones, regardless of any other influential factor, and all individual regional units converge to the same equilibrium. The steady-state equilibrium is a reasonable assumption in the case of a homogeneous sample of countries or regions (e.g. EU regions, US states, OECD countries, etc.; Mankiw et al. 1992). According to the conditional convergence hypothesis, reaching the equilibrium may be linked to other control variables (e.g. human capital, institutions, population growth rates, health status, etc.), although the differences between individual regions may remain constant. In other words, equilibrium differs by region and each particular economy approaches its own income level. The club convergence (based on Baumol 1986) hypothesis proposes that the territorial units belong to a particular group- or clubspecific equilibrium. For instance, regions of the EU converge with the EU average, while other regions approach other averages, if at all. The initial conditions of each individual group determine the convergence processes.

In terms of territorial units, methods, and indicators, convergence studies vary considerably (e.g. Rey-Montouri 1999, Oblath-Szörfi 2008, Goecke-Hüther 2016, Kotosz 2016, Yang et al. 2016).

The primary focus of our study is to test the hypothesis of absolute convergence in the study region. The starting point of neoclassical theories is the paper published by Solow in 1956. Despite its numerous criticisms and amendments (Romer 1986, Mankiw et al. 1992, Lengyel-Rechnitzer 2004), the theory describes an existing phenomenon and has been still widely used as a framework for territorial catch-up and convergence analyses (Rey-Montouri 1999, Konya-Guisan 2008, Oblath-Szörfi 2008, Vojinovic et al. 2009, Viegas-Antunes 2013, Bucur-Stangaciu 2015, Goecke-Hüther 2016, Tóth 2016).

The role of spatiality clearly gained importance in convergence studies (ReyMontouri 1999, Baumont et al. 2001, Paas et al 2007, Kocziszky 2013, Czaller 2016,

Regional Statistics, Vol. 8. No. 1. 2018: 49-77; DOI: 10.15196/RS080108 
Benedek-Kocziszky 2017). In other words, authors tend to abandon the theories of a closed economy that is independent of its surrounding regions and to account for interactions between regional economic actors. The resulting models assume that the impact of externalities between regions is similar to that of technology diffusion, while the regional transmission of accidental shocks plays only a negligible role in the longterm growth process (Kocziszky 2013). The notion of external impacts referred to in economics and territorial economics literature can be clearly attributed to Marshall (1920). The external economic impacts caused by agglomeration, result from the division of input and labour markets and from knowledge spillover (Varga 2009). The new economic geography provides a framework to interpret spatiality and economic growth; accordingly, the location of a region plays a major role in its economic activity. In other words, the economic situation of a region greatly depends on its actual location and neighbours. Therefore, poorer regions are better positioned to develop when they are located adjacent to richer regions (Baumont et al. 2001). The theory highlights the role of agglomeration externalities due to the spillover effects and interactions Marshall described. However, as far as the new economic geography is concerned, there is a general pessimism with regard to convergence and the coreperiphery phenomenon seems to emerge due to increasing returns (Paas et al 2007).

\section{Spatial interactions and convergence mainly in the Central and Eastern European countries}

In the Central and Eastern European (CEE) region (Czech Republic, Poland, and Hungary), Herz and Vogel (2003) find no evidence of absolute convergence at the NUTS 2 level between 1991 and 2002. According to their study, the economic catch-up was explained only in certain conditions (unemployment, sectoral employment) at the initial development level. Spatiality is expressed by country-specific factors (dummy variables) that are responsible for institutional and political impacts. In the ten new CEE member states, Smętkowski and Wójcik (2012) demonstrate unconditional convergence at the NUTS 3 level between 1998 and 2005. Although this finding is supported by the observation of catch-up at the macro level, there is also a clear evidence of polarisation within the individual countries. Spatial autocorrelation confirms the theory of growth poles for this period, meaning that city regions and their immediate vicinity represent growth centres; however, regional inequalities are also widening simultaneously. The poorest regions also show convergence, but at a very low speed, and a clear backwardness is indicated by the distance in economic catch-up. These two types of regions form a separate convergence club in the study period. Hegerty (2016) studies, in terms of the main economic sectors, the catch-up chances of the eleven new CEE member states at the NUTS 3 level between 2000 and 2013. The study included the industrial, construction, finance (Umantsiv-Ishchenko 2017), insurance, and real estate sectors as well as gross value

Regional Statistics, Vol. 8. No. 1. 2018: 49-77; DOI: 10.15196/RS080108 
added. The absolute beta-convergence analysis produced significant results only in exceptional cases. Although convergence could be found in agriculture and construction (Hungary), construction and industry (Croatia and Slovenia), and construction (the Baltic states), no overall convergence could be identified in a territory consisting of 233 NUTS 3 regions. High growth hot spots, identified with Getis-Ord local $G$ statistics, were present in the Baltic states, Bulgaria, and Romania, while cold spots could be detected in Poland and Croatia. Using the $\sigma$-method, Kotosz (2016) studies local convergence in the V4 countries at the NUTS 3 level between 2000 and 2013. According to his conclusion, areas of permanent divergence occur most frequently, while areas of permanent convergence are rare. As Kotosz and Lengyel's (2017) analysis demonstrates, the V4 countries show no significant betaconvergence at the NUTS 2/3 level between 2000 and 2014, while national divergence is present, again in terms of growth. The authors clearly show the positive impact of agglomeration benefits on economic growth and the twin-peaks phenomenon of convergence clubs in their study area. Benedek and Kocziszky (2017) also study the convergence trends of the V4 countries at the NUTS 2 level in terms of economic performance and social well-being. According to their findings, the convergence or divergence trends are strongly linked with regional polarisation and peripheralisation. Their calculations prove the emergence of convergence clubs. In the lack of sigma- and beta-convergence, local convergence exists within the clubs of the NUTS 2 regions. The findings confirm that peripheral regions are stuck in a lower development phase: they show convergence within the convergence club but their position has not improved considerably in the long run.

\section{Study questions}

As the Treaty of Rome already set forth the importance of reaching economic and social cohesion, our study deals with convergence along the lines of these two dimensions. Apart from the politically declared dual-target scheme, treating economic and social cohesion separately is also justified by the fact that there is no straightforward relationship between economic and social development (UNDP 2010, Rodrigez-Pose-Tselios 2015). Furthermore, our study abandons the theory of closed economies and focuses on regional correlations, including spatial interactions.

In view of the foregoing, our study questions are as follows:

- How do economic and social convergence occur at the regional level in Central and Eastern Europe?

- How do spatial interactions contribute to the convergence of social and economic development?

- What are the differences between economic convergence and social convergence?

- What are the local peculiarities of catch-up for the two dimensions?

Regional Statistics, Vol. 8. No. 1. 2018: 49-77; DOI: 10.15196/RS080108 


\section{Materials and methods}

The mathematical-statistical framework of our study relies on the absolute convergence test. Based on Barro and Sala-i-Martin (1990) and Vojinovic et al. (2009), we study cross-sectional data through the absolute $(\beta-)$ convergence hypothesis with the following regression equation:

$$
\frac{1}{T} \ln \frac{y_{i, T}}{y_{i, 0}}=\beta_{0}+\beta_{1} \ln y_{i, 0}+\varepsilon_{i},
$$

where $\ln y_{T}$ and $\ln y_{0}$ are the natural logarithms of the convergence index in region $i$ during the first and last study years, $\beta_{0}$ is the constant, $\varepsilon_{i}$ is the residual, and $T$ is the time of observation. We use the following formula to estimate the $\beta$ coefficient, which shows the speed of convergence. $\beta$ on the right side of the formula comes from the above regression equation and indicates the steepness of the function curve $\left(\beta_{1}\right)$.

$$
\beta=-\frac{1}{T} \ln \left(1+\beta_{1} T\right)
$$

We can also use this value to determine the half-life of convergence; that is, the time required to cover half the road leading to full convergence within the study region if the speed of convergence remains unchanged (Oblath-Szörfi 2008). We can measure the half-life of convergence using the formula $\tau=\frac{\ln 2}{\beta}$.

We supplement the performance convergence test with an analysis of the inequalities of development variables. Our purpose is to demonstrate that betaconvergence is coupled with a decrease (sigma-convergence), stagnation, or increase in (territorial) differences. Some authors (Barro and Sala-i-Martin 1990, OblathSzörfi 2008) claim that beta-convergence and sigma-convergence are interrelated, and that beta-convergence is a necessary, but not sufficient, condition for sigmaconvergence. However, Quah's (1993) findings show, sigma-convergence may emerge even without the presence of beta-convergence. Sigma-convergence is shown through the population-weighted coefficient of variation.

As traditionally beta-convergence tests fail to account for spatiality (Kotosz 2016), we supplement our analyses with this aspect. We express this with the help of Global Moran's I. We use the global autocorrelation test to study spatial dependence and use the global approach to reveal the average performance and growth patterns of the study regions.

$$
I=\frac{n}{2 A} \frac{\sum_{i=1}^{n} \sum_{j=1}^{n} \delta_{i j}\left(y_{i}-\bar{y}\right)\left(y_{j}-\bar{y}\right)}{\sum_{i=1}^{n}\left(y_{i}-\bar{y}\right)^{2}},
$$

Regional Statistics, Vol. 8. No. 1. 2018: 49-77; DOI: 10.15196/RS080108 
where $n$ is the number of spatial units, $y_{i}$ and $y_{j}$ are variables in the individual spatial units, $\bar{y}$ is the arithmetic mean of the relevant variable, $A$ is the number of contiguities, and $\delta_{i j}$ is 1 when $i$ and $j$ are neighbours, and 0 otherwise (Tóth 2014).

In order to avoid inconsistent estimates, we use the ordinary least squares (OLS) regression as well as the maximum likelihood spatial error (ML SEM), maximum likelihood spatial lag (ML SLM), and spatially weighted least squares (SWLS) models for our absolute convergence tests (Anselin 2005, Kelejian-Prucha 2010, Chasco 2013). We conducted the spatial econometric examinations using the GeoDa 1.12 and the GeoDaSpace 1.0 software packages.

Based on the average convergence of the overall study territory, we also wish to show the individual paths of the various regions. We can calculate and interpret the speed of convergence not only for the overall study territory, but also for each region (Oblath-Szörfi 2008). First, we describe the narrowing of the development gap (i.e. the rate of progress of the relevant region towards the established target value) for 2004-2014, and then we determine the individual half-life convergence values.

We measure the narrowing of individual development gaps (i.e. the annual speed of convergence) as follows:

$$
\beta=\frac{\ln \left[\left(1-R Y_{t 1}\right) /\left(1-R Y_{t 0}\right)\right]}{T},
$$

where $R Y_{t}=\left(T D_{t, i}\right) /\left(T D_{t, j}\right)$. TD (territorial development) is the regional development index, while $i$ is the given region and $j$ is the reference region. $t_{0}$ and $t_{1}$ represent the base period and current period, respectively. $T$ indicates the number of years (Oblath 2014). With the individual $\beta$ parameter and the same formula above, we calculate the half-life of the convergence by region (OblathSzörfi 2008).

The base data needed for the tests were made available by Eurostat. For our analyses, we use economic development indices (gross domestic product [GDP] per capita, purchasing power parity [PPP]) and the human development index (HDI), which considered one of the main indicators of social development. HDI, which is also a tool to express regional well-being, consists of four indices: household income per capita (expressed as purchasing power consumption standard [PPCS]), population share of only primary education, population share of tertiary education, and life expectancy at birth (Bubbico-Dijkstra 2011). Bubbico and Dijkstra (2011) provides the method to edit an index. We supplement this know-how with the use of fixed minimum and maximum values to enable time-based comparisons (see Trabold-Nübler 1991). Our choice is justified by the fact that the applied base di-

Regional Statistics, Vol. 8. No. 1. 2018: 49-77; DOI: 10.15196/RS080108 
mensions have different content and that the minima and maxima applied in the global analyses cannot be used in more developed regions. ${ }^{1}$

Our tests cover the period of 2004-2014, so our findings are formulated based on the changes observed during this period.

The observation area is Central and Eastern Europe, which includes the NUTS 2 regions of Poland, the Czech Republic, Slovakia, Hungary, Slovenia, Romania, Bulgaria, Germany, and Austria according to our definition. We include the last two countries because they act as the gravity centres and main economic and financial partners for the new member states (Körösi 2015). Furthermore, as Tagai (2004), (2011) and Balogh (2017) state, Germany has an outstanding role with regard to the interactive processes of Central and Eastern Europe. Due to its vicinity to the region, Germany has such a compelling economic weight - perceived as outstanding from the CEE's point of view - in the modelled system of spatial interrelations, which rarely concedes its primacy to local actors.

Within the framework of our study, EU membership represents, at least partly, the requirement of 'homogeneous spatial units'. Furthermore, the group treatment of the study region is justified by the common history, the resulting current relationships, and the spatial structure links (Gorzelak 2001, 2006, Rechnitzer-Smahó 2011), as well as the joint opportunities for transnational development projects (Strategy for the Danube Region and Central Europe programmes [Interreg VB]).

\section{Results}

First, we analysed the economic and well-being interrelations prevailing in the first and last years of the study period (see Figure 1), both of which show a strong and positive relationship between the economic and social dimensions, with the coefficients of determination ranging from $81.1 \%$ to $82.5 \%$. This means that a higher GDP per capita is associated with a similarly high social development value. As a shrinking range for 2014 occurs at higher levels in Figure 1, we can assume a catchup for both variables. Based on our preliminary results, we may accept McGillivray's (1991) criticism, which was among the first to challenge the usefulness of HDI on the grounds of its close relationship, with GDP per capita (which was still included in the index in 1990), among others. The author claims that the well-being index is just another redundant index that cannot produce a more refined picture of development than that obtained with the traditional economic performance index.

1 Applied minimum and maximum values: household income per capita: 2,500-25,000 PPCS; population share of only primary education: $2.0-40.0 \%$; population share of tertiary education: $5.0-40.0 \%$; life expectancy at birth: 65-85 years.

We calculate the education index as follows: $I_{\text {education }}=\frac{1}{3}\left(1-I_{\text {low education }}\right)+\frac{2}{3}\left(I_{\text {higher education }}\right)$.

We calculate HDI using the geometric mean based on the UNDP (2016).

Regional Statistics, Vol. 8. No. 1. 2018: 49-77; DOI: 10.15196/RS080108 
Figure 1

Regression relationships between economic production and social well-being

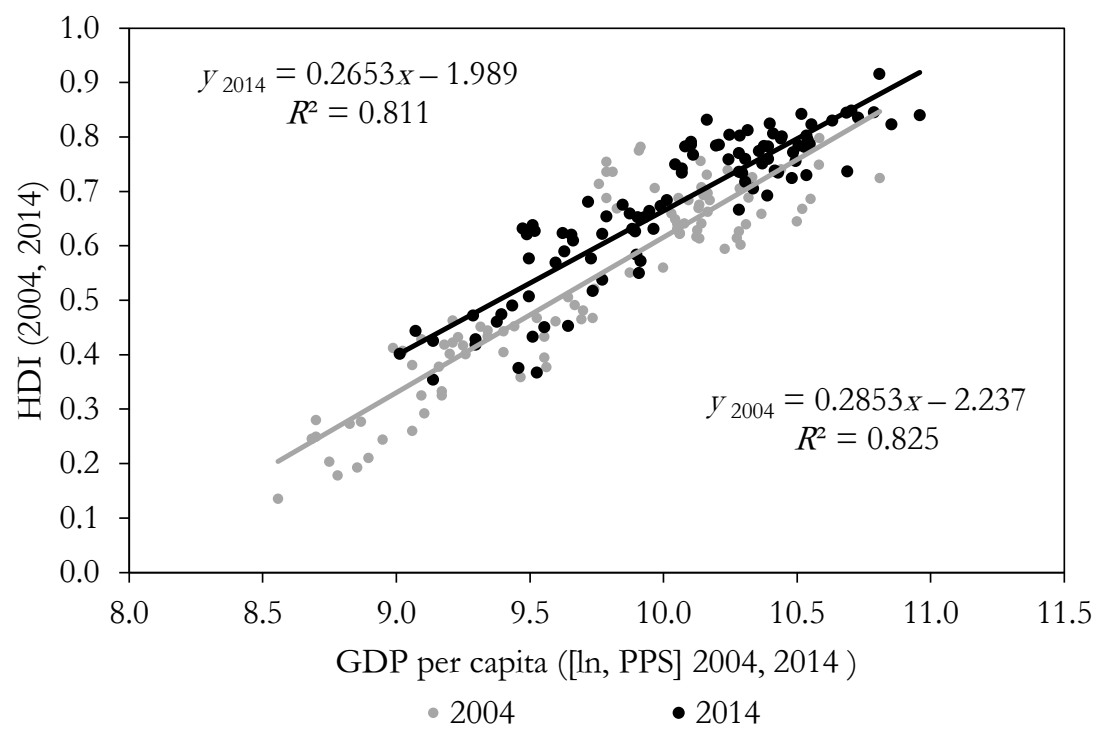

Note: Here and in the following figures and tables, HDI - human development index; GDP - gross domestic product; PPS - purchasing power standard.

To find more detailed relationships, we describe the correlation coefficients of the base data required for the beta-convergence tests on the basis of Pearson coefficients (see Table 1). We supplement them with the components of HDI. The matrix shows the extent of joint movements both for the initial development levels and for the growth rates. The static correlation coefficients (above the main diagonal) show clearly significant and unidirectional relationships between economic and social development and the components of the latter. This means that the social and economic characteristics we review strengthen each other and that there is a strong relationship between them, except between GDP per capita and the education index.

The dynamic relationships (below the main diagonal) show similar directions: the growth of one factor moves together with that of another, but the strength of the relationships is more diverse and can produce a more sophisticated picture. There is a strong synergic correlation in most cases, although there is only a weak/average dynamic link between education and income indicators. We must highlight the relationship between income indicators and life expectancy at birth growth. Additionally, the household income per capita shows a stronger relationship than GDP per capita does. This confirms Stiglitz, Sen and Fitoussi's (2009) claim that household income is a better proxy for quality of life than GDP.

Regional Statistics, Vol. 8. No. 1. 2018: 49-77; DOI: 10.15196/RS080108 
Correlations between initial development levels (2004) and growth rates (2014/2004)

\begin{tabular}{l|c|c|c|c|c}
\hline \multicolumn{1}{c|}{ Denomination } & HDI & $\begin{array}{c}\text { Income } \\
\text { per capita }\end{array}$ & $\begin{array}{c}\text { Life } \\
\text { expectancy }\end{array}$ & $\begin{array}{c}\text { Education } \\
\text { index }\end{array}$ & $\begin{array}{c}\text { GDP } \\
\text { per capita }\end{array}$ \\
\hline HDI & - & $0.939^{* *}$ & $0.935^{* *}$ & $0.880^{* *}$ & $0.895^{* *}$ \\
Income per capita & $0.876^{* *}$ & - & $0.947^{* *}$ & $0.705^{* *}$ & $0.948^{* *}$ \\
Life expectancy & $0.826^{* *}$ & $0.740^{* *}$ & - & $0.734^{* *}$ & $0.884^{* *}$ \\
Education index & $0.705^{* *}$ & $0.431^{* *}$ & $0.587^{* *}$ & - & $0.691^{* *}$ \\
GDP per capita & $0.739^{* *}$ & $0.895^{* *}$ & $0.651^{* *}$ & $0.382^{* *}$ & -
\end{tabular}

Note: The correlation coefficients of the static indicators (initial level) are shown above the main diagonal of the correlation matrix, while those of the dynamic indicators (growth rate) are displayed below the main diagonal. ** stands for a significance level of 0.01 .

We now lay the foundation for the findings of our absolute convergence tests. We start by analysing the convergence relationships by running an OLS regression. Once we test the spatial dependence of random errors (Moran's I), we supplement each regression with the spatial features of the required specification. At the start of our spatial econometric assessment, we need to define the spatial structure of the CEE territory. In particular, we must specify the regions and their direct neighbours (Váry 2017). We use the following to select the appropriate spatial weight matrix. For the dependent variables (growth rates), we run Moran's $I$ index with the use of various distance matrices. We apply first-order queen, and 175, 200, and $225 \mathrm{~km}$ distance spatial weight matrices.

According to our analyses, spatiality is best described by the first-order queen contiguity because Moran's $I$ shows the highest and the most significant value here: 0.830 for HDI and 0.694 for GDP per capita growth. The high and significant values of Moran's I confirm the strong nature of spatial autocorrelation, which means that spaces of similar growth rates form clusters within the territory. Figures 2 and 3 show the spatial growth relationships between spaces by HDI and GDP per capita. Based on the growth indices, the figures indicate the phenomenon of East-West dichotomy. As to HDI, we see consistently continuous and significant low-low (LL) spaces (having low HDI growth just as their direct neighbours do), representing mostly the German regions. The eastern part of the territory displays a similarly continuous high-high $(\mathrm{HH})$ cluster (the spaces belong to which and their neighbours show high HDI growth) consisting of Romania as a whole, Bulgaria excluding Yuzhen Tsentralen (Southern Central Planning Region), the Southern Great Plain of Hungary, and the Mazowieckie (Warsaw) Region of Poland.

Regional Statistics, Vol. 8. No. 1. 2018: 49-77; DOI: 10.15196/RS080108 
Spatial autocorrelation pattern of the HDI growth by Moran's I, 2004-2014

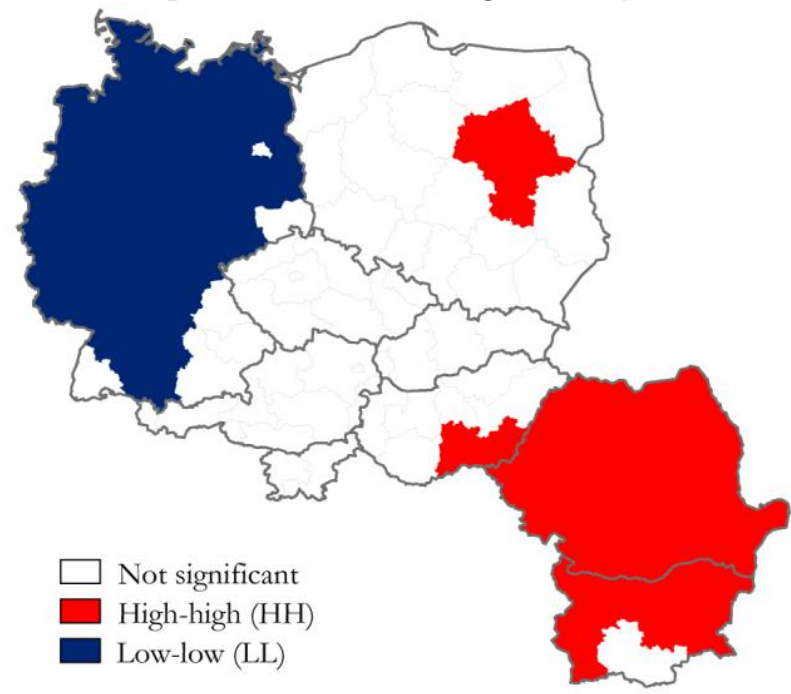

The picture is similar for economic growth as well: the East-West division is evident. Western spaces are less homogeneous: Germany's northern, central, and southern regions are displayed as an independent cluster centre joined by several Austrian spatial units and two Slovenian regions. The eastern part shows an $\mathrm{HH}$ cluster consisting of Romania as a whole; Severoiztochen and Severen Tsentralen of Bulgaria; Poland excluding Zachodnio-Pomorskie, Lubuskie, Dolnoslaskie, Podkarpackie, and Pomorskie; and Strední Morava of the Czech Republic. Having the lowest community GDP per capita (30\% of the EU average at 2014 PPP), Severozapaden (Northwestern Planning Region) of Bulgaria is a low-high (LH) spatial outlier; that is, it has low economic growth, while its direct neighbours show high economic growth. This phenomenon indicates a halt of the catch-up process in the study period.

A similar study by Rodríguez-Pose and Tselios (2015), dealing with social wellbeing in the regions of Western Europe, explains the significant spatial autocorrelation with the 'traditional' social-economic interactions (knowledge and information technology spillover, trade, movement of labour and capital, economies of scale, transfer payments, etc.) taking place between the regions. According to the same study, the strong congruity may be further explained by such other factors as the roles of national cultures, institutions, and macro level policies. The spatial characteristics of these roles are also evident in the results of our spatial analyses regarding economic growth and social development. This means that, under the conditions of our current analyses, we may also calculate the differentiating impacts of national factors on convergence spatiality.

Regional Statistics, Vol. 8. No. 1. 2018: 49-77; DOI: 10.15196/RS080108 
We continue our analyses using this first-order queen weight matrix. Although we tried to run our regression analyses with several other matrices, they did not lead to any real change in the main parameters. According to our results in Tables 2 and 3 , the CEE region shows unconditional convergence during the study period.

Figure 3

Spatial autocorrelation pattern of the GDP per capita growth by Moran's $I$, 2004-2014

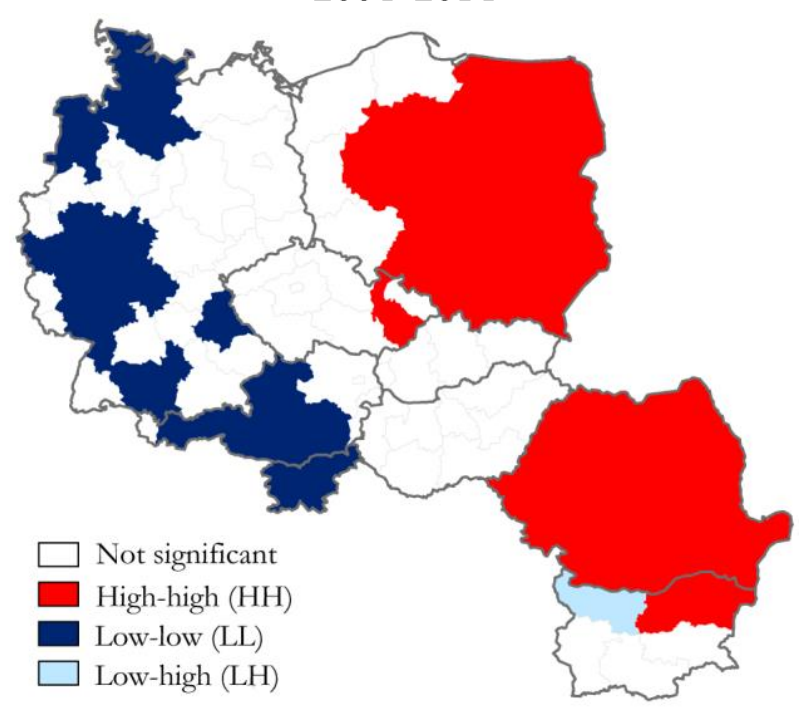

The regression $\beta$ coefficient indicating convergence is negative for both indices, meaning that the less developed regions show higher growth rates and vice versa. The strength of the relationships varies greatly for the OLS regressions $(48.9 \%$ vs. $90.5 \%$ ). As to HDI, the slope is steeper and, consequently, the convergence is stronger. According to the findings of our global autocorrelation test (Moran's I) performed on residual errors, the models still hold a lot of information. We use Lagrange multipliers to provide information for the regressions supplemented with spatial characteristics. Accordingly, we supplemented the regressions with the spatial lag errors of the OLS regression for social development change and with the $n$ values of the dependent variable for GDP per capita. In other words, we used the spatial error model (SEM) for the former and the spatial lag model (SLM) for the latter (for details of the decision process, see Anselin 2005, p. 218.). 
Table 2

Absolute convergence of HDI by traditional (OLS) and spatial regressions

\begin{tabular}{l|c|c|c}
\hline \multicolumn{1}{c|}{ Denomination } & OLS & ML SEM & SWLS (HET) \\
\hline Constant & $0.201^{* * *}$ & $0.185^{* * *}$ & $0.187^{* * *}$ \\
& $(35.336)$ & $(21.354)$ & $(12.831)$ \\
HDI (ln, 2004) & $-0.044^{* * *}$ & $-0.040^{* * *}$ & $-0.040^{* * *}$ \\
& $(-30.447)$ & $(-18.415)$ & $(-11.186)$ \\
$\lambda$ & - & $0.735^{* * *}$ & $0.741^{* * *}$ \\
$R^{2}$ & 0.905 & $(9.821)$ & $(7.986)$ \\
MCN & 20.070 & 0.947 & 0.906 \\
Log likelihood & 370.069 & - & - \\
Akaike information criterion & -736.137 & -777.150 & - \\
Breusch-Pagan-test & $4.002^{* *}$ & $23.837 * * *$ & - \\
Likelihood ratio test & - & $41.0133^{* * *}$ & - \\
LM test (error) & $45.151^{* * *}$ & - & - \\
Robust LM (error) & $25.916^{* * *}$ & - & - \\
LM test (lag) & $23.628^{* * *}$ & - & - \\
Robust LM (lag) & $4.393^{* *}$ & - & - \\
Moran's $I$ (residuals) & $0.455^{* * *}$ & 0.018 & - \\
Speed of convergence (\%) & 5.830 & 5.080 & 13.430 \\
Half-life (year) & 11.890 & 13.640 & \\
& & & - \\
\hline
\end{tabular}

Note: Here and in the following table(s), OLS - ordinary least squares; ML SEM - maximum likelihood spatial error model; SWLS (HET) - spatially weighted least squares (robust inference of the estimator covariance matrix in presence of both spatial heteroskedasticity and autocorrelation); MCN - multi-collinearity condition number; LM - Lagrange multiplier. ${ }^{* *}$ and $* *$ indicate significance at 0.01 and 0.05 , respectively. The spatial weight matrix is based on first-order queen contiguity. See the $t$-(OLS) and $z$-score (ML, SWLS) values in parentheses.

For the maximum likelihood regressions, we obtain information on model suitability, not only from the $R^{2}$, but also from the log likelihood (higher values are better) and Akaike information criterion (lower values are better). Accordingly, adding congruity values improves the explanatory power of the models for both dependent variables. The likelihood ratio test, which is used to test spatial dependence (i.e. the applied weight matrix), demonstrates that the processes in neighbouring regions significantly affect the strengthening of the two phenomena. Due to the heteroscedasticity of the residuals in the case of HDI convergence, we use a robust estimation of the covariance matrix here (SWLS HET, Kelejian-Prucha 2010, Chasco 2013). When supplemented with spatiality, the models provide a more balanced picture in terms of explanatory power (for the SWLS regression, only the $R^{2}$ provides information on the best fit). Therefore, we can conclude that convergence does not depend only on the initial conditions. In fact, it is also clearly influenced by phenome-

Regional Statistics, Vol. 8. No. 1. 2018: 49-77; DOI: 10.15196/RS080108 
na occurring in the neighbouring regions or in the countries encompassing a given region (spillover effects). These phenomena affect not only economic convergence but have an obvious impact on social development as well.

Table 3

\begin{tabular}{l|c|c}
\multicolumn{2}{c}{$\begin{array}{c}\text { Absolute convergence of GDP per capita by traditional (OLS) } \\
\text { and spatial regressions }\end{array}$} \\
\hline \multicolumn{1}{c}{ Denomination } & OLS & ML SLM \\
\hline Constant & $0.206^{* * *}$ & $0.059^{* * *}$ \\
GDP per capita (ln, 2004) & $(11.503)$ & $(3.253)$ \\
& $-0.018^{* * *}$ & $-0.005^{* * *}$ \\
$W$ & $(-9.586)$ & $(-2.995)$ \\
& & $0.729^{* * *}$ \\
$R^{2}$ & - & $(10.248)$ \\
MCN & 0.489 & 0.704 \\
Log likelihood & 15.550 & - \\
Akaike information criterion & 313.561 & 333.163 \\
Breusch-Pagan-test & -623.121 & -660.326 \\
Likelihood ratio test & $5.073^{*}$ & 6.068 \\
LM test (lag) & - & $39.205^{* * *}$ \\
Robust LM (lag) & $28.108^{* * *}$ & - \\
LM test (error) & $26.254^{* * *}$ & - \\
Robust LM (error) & $9.230^{* * *}$ & - \\
Moran's I (residuals) & $7.445^{* * *}$ & - \\
Speed of convergence (\%) & $0.207^{* * *}$ & -0.021 \\
Half-life (year) & 1.950 & 0.520 \\
& 35.620 & 132.790 \\
\hline
\end{tabular}

Note: ML SLM - maximum likelihood spatial lag model; $W$ - spatially lagged dependent variable. *** and * indicate significance at 0.01 and 0.10 , respectively. The spatial weight matrix is based on first-order queen contiguity. See the $t$ - (OLS) and $z$-score (ML) values in parentheses.

Tables 2 and 3 list the annual speeds of convergence and the half-life figures based on the regression $\beta$ values calculated for the individual models. Although the regression $\beta$ values have negative signs, the speeds of convergence (and the halflives computed from them) show different patterns. The average growth in social development looks better: the annual speed of convergence always exceeds $5 \%$ and the half-life never exceeds 15 years. Economic performance is coupled with a much lower speed of convergence (approximately $2 \%$, which is almost the same as the estimate obtained using Mankiw et al.'s (1992) methodology for OECD countries or Dedák and Dombi's (2009) estimate for CEE counties), but it drops to one quarter of its original value (while the half-life increases in parallel) when spatiality comes into the picture. The neighbourhood effects lead to a downward adjustment in the

Regional Statistics, Vol. 8. No. 1. 2018: 49-77; DOI: 10.15196/RS080108 
original OLS model in both cases, while for economic development, the phenomena occurring in directly neighbouring regions are more pronounced.

Several prior studies highlight the presence of national differentiation in the CEE convergence process (Herz-Vogel 2003, Hegerty 2016, Kotosz-Lengyel 2017) and, in particular, the great differences both between and within the countries in this regard. Our study focuses on nine countries. However, introducing that many (eight) convergence club dummy variables produced severe multicollinearity. Thus, we created two dummy variables (d_2004, d_2007), indicating the accession date in the EU accession function, and used Germany and Austria as references.

Table 4

Institutional club convergence

\begin{tabular}{l|c|c}
\hline \multicolumn{1}{c|}{ Denomination } & HDI & GDP per capita \\
\hline Constant & $0.175^{* * *}$ & $0.085^{* * *}$ \\
& $(12.609)$ & $(2.640)$ \\
TD (ln, 2004) & $-0.038^{* * *}$ & $-0.006^{*}$ \\
& $(-11.626)$ & $(-1.858)$ \\
d_2004 & $0.005^{* *}$ & $0.010^{* * *}$ \\
& $(2.406)$ & $(3.162)$ \\
d_2007 & $0.007^{*}$ & $0.022^{* * *}$ \\
& $(1.798)$ & $(4.655)$ \\
$R^{2}$ & 0.908 & 0.572 \\
MCN & 55.250 & 78.543 \\
Log likelihood & 373.005 & 323.790 \\
Akaike information criterion & -738.011 & -639.581 \\
Breusch-Pagan-test & $13.641^{* * *}$ & $47.336^{* * *}$ \\
LM test (error) & $43.126^{* * *}$ & $23.876^{* * *}$ \\
LM test (lag) & $25.998^{* * *}$ & $27.363^{* * *}$ \\
Moran's $I$ (residuals) & $0.445^{* * *}$ & $0.331^{* * *}$ \\
Speed of convergence (\%) & 4.780 & 0.062 \\
Half-life (year) & 14.500 & 111.800
\end{tabular}

Note: TD - territorial development. ${ }^{* * *},{ }^{* *}$, and $*$ indicate significance at $0.01,0.05$, and 0.10 , respectively. See the $t$-score values in parentheses.

The convergence club approach also provides an opportunity to test the institutional impacts. Zeghni and Fabry (2008) study the role of institutions in human development in the transitional economies of CEE. The authors find a significant impact in countries that joined the EU in 2004 and 2007. They attributed the improvement in human development, achieved through market (creation and regulation) and political institutions (democracy and state federalism), to the application of the 'acquis communautaire' criterion. Therefore, the EU accession date may be

Regional Statistics, Vol. 8. No. 1. 2018: 49-77; DOI: 10.15196/RS080108 
considered an institutional development variable, the impact of which we also test. Our results confirm convergence, and the dummy variables (i.e. institutional clubs) have a significant impact on the growth of our development variables. According to the $t$-scores, this impact is more stable for HDI and GDP in the regions of countries that joined the EU in 2004 and 2007, respectively. Regardless of the significant presence of explanatory variables, the models present several errors. We should first mention the high level of multicollinearity. It actually demonstrates that the dummy variables are 'superfluous' because the convergence clubs are inherent in the static (initial) and dynamic data. We find evidence of spatial dependence in the models as well. This reinforces the summary statement of Váry (2017, p. 262.), according to which 'as all potentially decisive development factors (institutional quality, cultural attitudes, human capital, geographical aspects, etc.) correlate and interact with each other in a complex manner, it is difficult to identify the individual impacts of each explanatory variable on development'. Furthermore, the heteroscedasticity of the residuals compromises the reliability of regression estimates. As to social well-being, the regional dummy variables reduce the speed of convergence and increase halflife. For economic performance, the values are slightly better than those obtained with the spatial lag model. Due to multicollinearity and the heteroscedasticity, we did not run the spatial regressions.

Finally, the population-weighted coefficients of variation (CV) of the two development indices indicate territorial leverage; that is, sigma-convergence is coupled with declining regional differences between 2004 and 2014 (see Figure 4).

Figure 4

Sigma convergence and spatial autocorrelation of the development variables

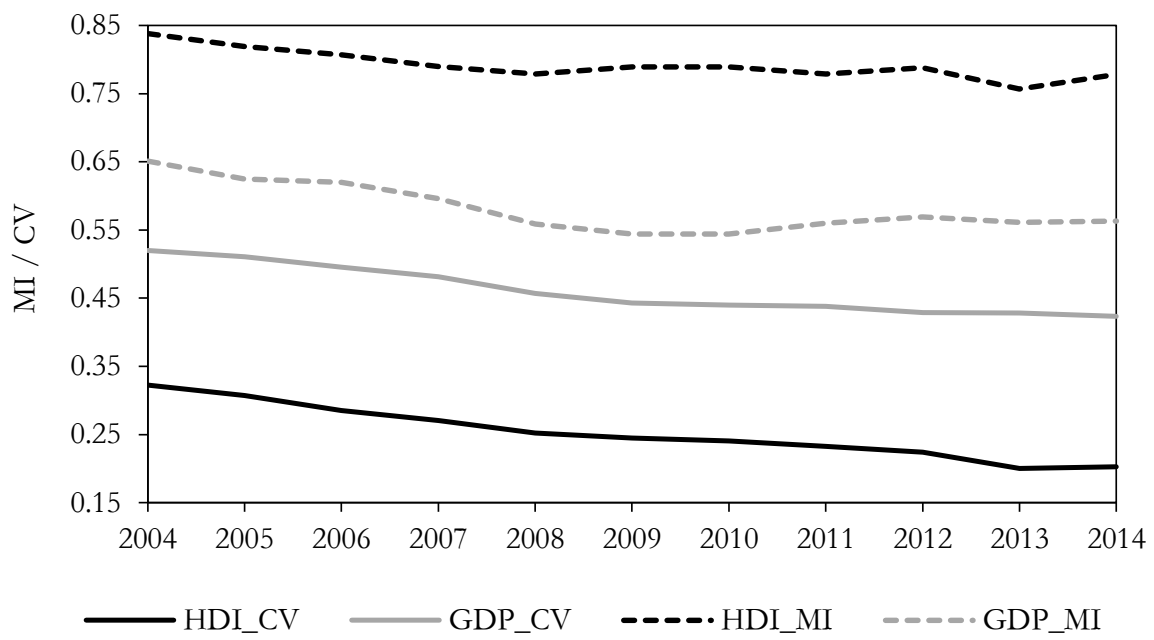

Note: MI - Moran's I; CV - population-weighted coefficient of variation.

Regional Statistics, Vol. 8. No. 1. 2018: 49-77; DOI: 10.15196/RS080108 
For GDP per capita, sigma-convergence shows greater variation and is clearly lower than that for HDI, leading to smaller regional inequalities and more balanced conditions. It is also evident in Figure 4 and from the data that there is a considerable decrease until 2008, followed by a sudden drop in the steepness of the curves, which may be the result of the economic crisis. We use regression trend calculations for both variables in order to determine whether we can consider the direction of regional differences reliable. We apply a logarithmic estimation for both HDI and GDP per capita to explain the trends that decrease with the highest speed/certainty. The coefficients of determination amount to $96.4 \%$ (HDI) and $91.5 \%$ (GDP per capita), the regression parameters (constant, $\beta_{1}$ ) are significant, ${ }^{2}$ and the equations reasonably explain the phenomenon of decreasing variation (leverage). In addition to $\mathrm{CV}$, we also analyse the global regional autocorrelation of the development variables to see how the effect of leverage may change the average spatial pattern and how the study area may separate into regions consisting of several sub-regions with different characteristics. The values of Moran's I move together with the CV values such that where a variable shows a lower coefficient of variation, there is a higher level of clusterisation (HDI) and vice versa (GDP per capita). The temporal evolution of the regionalisation is significant, with high explanatory power $\left(R^{2}\right.$ is $71.1 \%$ for HDI, $60.8 \%$ for GDP). ${ }^{3}$ In addition, there is another similarity: both CV and significant regionalisation tended to decrease until the start of the economic crisis, but CV decreased thereafter, while the spatial autocorrelation shows stagnation. Smętkowski $(2015$, p. 545.) calls this phenomenon 'diminishing spatial autocorrelation leading to convergence and mixed hierarchical and contagious diffusion'. This means that we can see both the emergence of hot spots in peripheral areas and contagious diffusion processes in the immediate vicinity of growth poles in the study area. We continue our study with local convergence analyses.

\section{Local convergence analyses without spatial parameters}

The local analyses are suitable for describing the individual paths of the various regions and showing the annual speed of convergence (narrowing in development gap) and the half-life value. Prior to such analyses, we must define a (reference) region for the catch-up target. Instead of choosing a NUTS 2 region, we select Austria's national performance as the catch-up target to achieve (Austria is a leader in the study region on both dimensions).

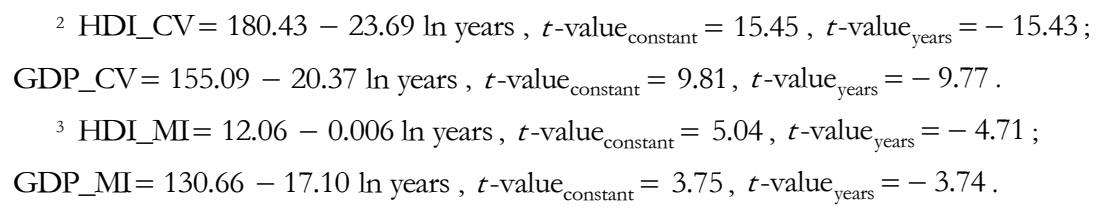

Regional Statistics, Vol. 8. No. 1. 2018: 49-77; DOI: 10.15196/RS080108 
Tables 5 and 6 list, by NUTS 2 region, the annual speed of convergence for HDI and economic performance, and the resulting half-lives. The tables contain the extreme values (maxima and minima) of the various countries, organised according to the annual speed of catch-up (the tables exclude regions that already caught up with the reference region). Figures 5 and 6 , linked with the calculations, give a better understanding of the spatial peculiarities.

The annual catch-up speeds required to reach Austria's level, vary greatly for both HDI and GDP per capita. Based on the growth in 2004-2014, we can group the individual regions into either the 'catch-up complete' or 'catch-up not complete' category. Just as in the global and spatial convergence analyses, the former indicator displays a stronger narrowing in the development gap. In the study regions, the Mazowieckie territorial unit (including Warsaw) of Poland shows the highest annual speed of convergence $(11.6 \%)$ and the Jihozapad territorial unit of the Czech Republic has the lowest value $(0.7 \%)$.

Table 5

Maximum and minimum values of the local speeds of HDI convergence, and the resulting half-lives, 2004-2014

\begin{tabular}{|c|c|c|c|}
\hline Country & Territorial unit & $\begin{array}{l}\text { Annual speed of } \\
\text { convergence, } \%\end{array}$ & Half-life, years \\
\hline \multirow{2}{*}{ Bulgaria } & Yugozapaden & -4.9 & 14.06 \\
\hline & Yugoiztochen & -1.5 & 45.91 \\
\hline \multirow{2}{*}{ Czech Republic } & Strední Cechy & -4.5 & 15.51 \\
\hline & Jihozapad & -0.7 & 103.91 \\
\hline \multirow{2}{*}{ Hungary } & Southern Great Plain & -2.6 & 26.27 \\
\hline & Central Hungary & - & catch-up not complete \\
\hline \multirow{2}{*}{ Poland } & Mazowieckie & -11.6 & 6.00 \\
\hline & Kujawsko-Pomorskie & -3.0 & 23.25 \\
\hline \multirow{2}{*}{ Romania } & Bucuresti-Ilfov & -9.8 & 7.10 \\
\hline & Sud-Est & -2.4 & 28.42 \\
\hline \multirow{2}{*}{ Slovenia } & Vzhodna Slovenija & -3.0 & 22.99 \\
\hline & Zahodna Slovenija & - & catch-up not complete \\
\hline \multirow{2}{*}{ Slovakia } & Východné Slovensko & -3.1 & 22.36 \\
\hline & Západné Slovensko & -2.0 & 33.98 \\
\hline \multirow{2}{*}{ Germany } & - & - & - \\
\hline & Saarland & - & catch-up not complete \\
\hline \multirow{2}{*}{ Austria } & Burgenland & -10.2 & 6.80 \\
\hline & Steiermark & - & catch-up not complete \\
\hline
\end{tabular}

With regard to HDI catch-up, we can see a clear East-West dichotomy. For CEE, the eastern part is characterised by convergence, while the western part typi-

Regional Statistics, Vol. 8. No. 1. 2018: 49-77; DOI: 10.15196/RS080108 
cally shows developed spaces categorised either as 'catch-up complete' or 'catch-up not complete'. The new member states, with two exceptions, experienced a strong trend of catch-up mostly in the capitals or in the neighbouring regions of the capitals. The Prague and the Bratislava regions exceeded the average Austrian quality of life in 2011 and 2014, respectively. The annual narrowing in the development gap is strong in the Warsaw (11.6\%) and Bucharest $(9.76 \%)$ regions. ${ }^{4}$ With its annual speed of almost 5\%, the Sofia region (Yugozapaden) excels among the study regions, while the Polish region including three big hubs besides the capital city (Malopolskie, Dolnoslaskie, and Podlaskie) shows an annual speed above 5\%. The higher catch-up rate of the more developed urban areas in these countries indicates a process of divergence.

We can also see the 'catch-up not complete' category in the new member states: despite a slight increase, the basic trend shows a downward adjustment from the reference value in Central Hungary and Zahodna Slovenija (Ljubljana). In 2004, the former stood at $90 \%$, while the latter nearly reached the Austrian average, but by 2014 , the former dropped to $83 \%$ and the latter increased to $98 \%$ of the reference value. For the region of Budapest, the relative lag is attributable to the decline in household incomes (alone in the study area), and for Ljubljana, the smallest increase can be observed between 2004 and 2014. In the case of increase in life expectancy, both regions are in the upper third. While the improvement in the education index also represents the best third in the Slovenian capital region, in Central Hungary, there is only a moderate improvement.

We can see a similar but somewhat different process in Germany and Austria as well. The German and Austrian regions in the 'catch-up not complete' and 'catch-up complete' categories exceeded the reference value in 2004 but showed a decline in social development in 2014. This phenomenon is typical in some $90 \%$ of the territorial units of the German-speaking countries. The only exceptions are Burgenland, Niederösterreich, Oberösterreich, and Vorarlberg: these are the only regions in which we can see convergence. The relative decrease in the majority of the regions is attributable to the lowest growth of all dimensions of HDI between 2004 and 2014.

\footnotetext{
${ }^{4}$ It is worth examining the delineation of the two regions. The Mazowieckie region represents the classic example of aggregation information loss, the NUTS 2 region consists of eight sub-regions with different levels of economic development. Three out of the eight sub-regions exceeded the 75 percent of GDP per capita (PPP) value of the EU28 average (Miasto Warszawa: 196\%; Warszawszki Zachodni: 89\%; Plocki: 111\%), and the remaining ones vary between $50 \%$ and $60 \%$. However, Bucharest forms a NUTS 2 region only with the sub-region located in its immediate vicinity (Bucuresti-Ilfov).
}

Regional Statistics, Vol. 8. No. 1. 2018: 49-77; DOI: 10.15196/RS080108 


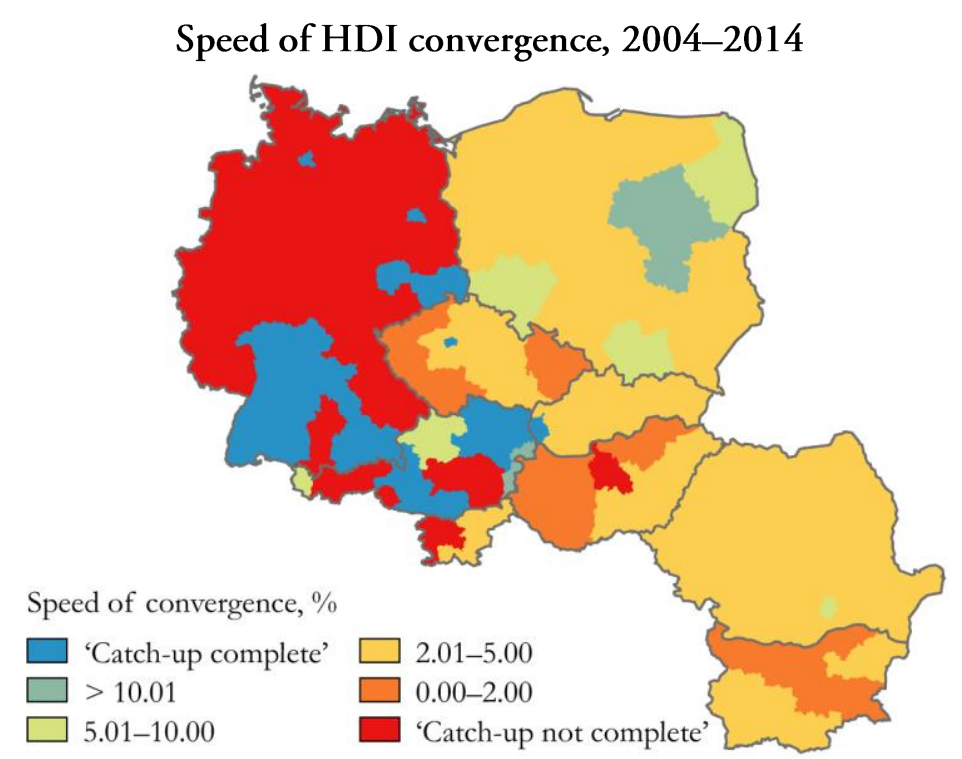

Figure 5

Furthermore, the speed of convergence shows a clear-cut differentiation at the national level. This indicates, again, the importance of country-specific effects and convergence clubs. The narrowing of the development gap is fairly high in Poland $(4.6 \%)$, Slovakia $(2.5 \%)$, and Romania $(4.18 \%)$. The Czech Republic, Hungary, Bulgaria, and Slovenia show various catch-up trends. The first three have a low speed of convergence, which strengthens the divergence process in the less developed/depressed regions (Northern Hungary, Southern Transdanubia [Hungary], Severozapaden, Severen Tsentralen [Bulgaria], and Severozápad [Czech Republic]). The phenomenon of club formation is obvious also in Germany: most southern provinces (Baden-Württemberg, Bavaria) show downward adjustment, but maintain their pace. The regions of Berlin, Hamburg, Dresden, and Leipzig are in a similar situation. There is a high performing but relatively lagging convergence club in the central and northern part of Germany. The reference region is not uniform either: Burgenland, Oberösterreich, and Vorarlberg are strongly catching up, while there is a downward adjustment in the Vienna region.

The speed of convergence of GDP per capita also shows both extremes ('catchup complete', 'catch-up not complete'), but their ratio differs from the HDI figures. The catch-up not complete category is particularly small, which is an evident sign of the division between the two dimensions. When comparing the two figures, this phenomenon becomes especially spectacular in the central and northern part of Germany.

Regional Statistics, Vol. 8. No. 1. 2018: 49-77; DOI: 10.15196/RS080108 
Maximum and minimum values of the local speeds of GDP per capita convergence, and the resulting half-lives, 2004-2014

\begin{tabular}{|c|c|c|c|}
\hline Country & Territorial unit & $\begin{array}{l}\text { Annual speed of } \\
\text { convergence, } \%\end{array}$ & Half-life, years \\
\hline \multirow{2}{*}{ Bulgaria } & Yugozapaden & -3.5 & 19.66 \\
\hline & Severozapaden & -0.3 & 256.29 \\
\hline \multirow{2}{*}{ Czech Republic } & Jihovýchod & -2.0 & 34.39 \\
\hline & Severozápad & -0.3 & catch-up not complete \\
\hline \multirow{2}{*}{ Hungary } & Central Hungary & -2.1 & 32.41 \\
\hline & Southern Transdanubia & -0.2 & 450.45 \\
\hline \multirow{2}{*}{ Poland } & Mazowieckie & -9.9 & 7.00 \\
\hline & Swietokrzyskie & -1.0 & 66.56 \\
\hline \multirow{2}{*}{ Romania } & Vest & -2.1 & 33.23 \\
\hline & Nord-Est & -1.0 & 68.61 \\
\hline \multirow{2}{*}{ Slovenia } & Vzhodna Slovenija & - & catch-up not complete \\
\hline & Zahodna Slovenija & - & catch-up not complete \\
\hline \multirow{2}{*}{ Slovakia } & Západné Slovensko & -2.9 & 24.11 \\
\hline & Východné Slovensko & -1.2 & 55.66 \\
\hline \multirow{2}{*}{ Germany } & Niederbayern & -11.1 & 6.24 \\
\hline & Trier & - & catch-up not complete \\
\hline \multirow{2}{*}{ Austria } & Steiermark & -1.9 & 36.45 \\
\hline & Burgenland & -0.0 & 1774.10 \\
\hline
\end{tabular}

A Hungarian region (Southern Transdanubia) produces the lowest positive value $(0.2 \%)$ and again, the Polish capital region (Mazowieckie) is the best performer $(9.9 \%)$ in the CEE area. The two phenomena are synergistic and moving together in both regions. Just like in the case of human development, Prague and Bratislava exceed the Austrian average in terms of economic performance. However, the two dimensions are not balanced in Bucharest, with the HDI slightly lagging behind. 
Speed of GDP per capita convergence, 2004-2014

Figure 6

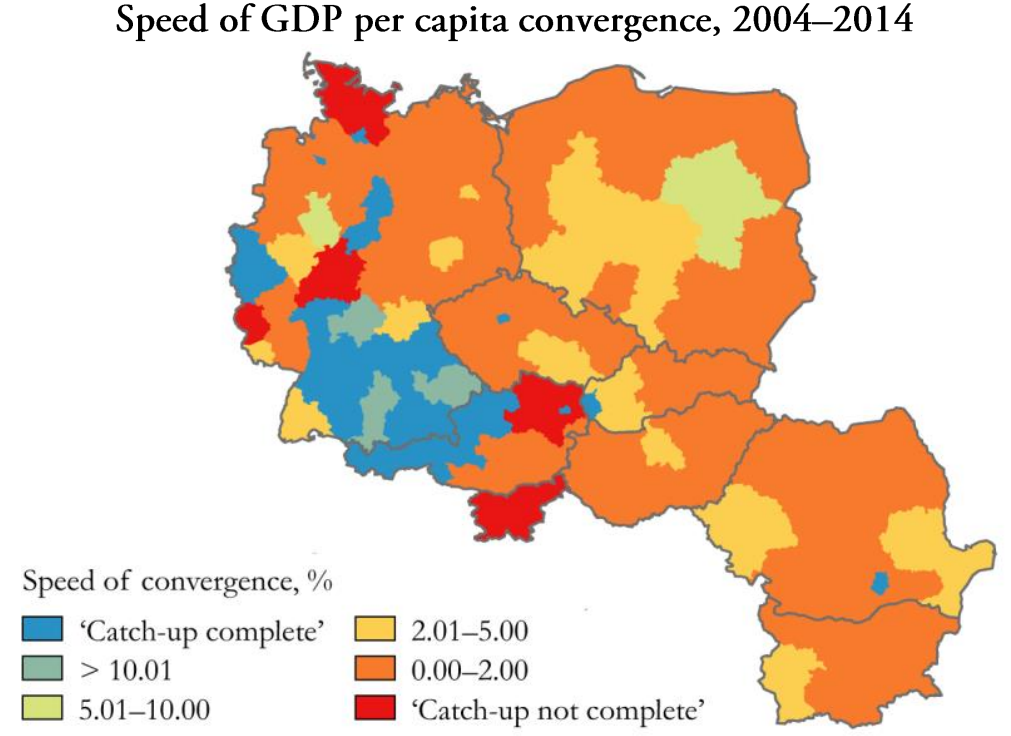

Central Hungary shows an opposite trend: the speed of convergence is positive for GDP per capita but negative for HDI. In the latter two cases, the issue of efficiency is also raised because a one-sided process of complex catch-up seems to favour only the GDP per capita dimension. In view of the growth rates of the 10-year period under review, Zahodna Slovenija failed to reach the reference region (as in the case of HDI). In the Yugozapaden region of Bulgaria, economic performance and human development 'walk hand in hand'. In the eastern territory, the main spaces for economic catch-up, in addition to capital cities, are the regions that include developed cities. In particular, the regions of Poznan, Wroclaw, Katovice, or Lodz (Wielkopolskie, Dolnoslaskie, Slaskie, Lodzkie) in Poland; the region of a major Brno sub-centre (Jihovichod) in the Czech Republic; and the region of Západné Slovensko (Trnava, Trencin, Nitra) adjacent to the capital city in Slovakia show high-level convergence with Austria. Romania's second largest growth pole is the Vest region, which includes MEGA (Metropolitan European Growth Area) (Timişoara, Arad), which has European implications, and the strategically positioned Sud-Est region, which attracts a huge amount of foreign working capital (AllenOvery 2011). Apart from these regions, the eastern territory shows only low catchup speeds $(0-2 \%$ per year). In terms of economic performance, it indicates divergence within the countries. Slovenia is an exception, as even Vzhodna Slovenija shows a downward adjustment. This region is also an exception in that HDI has a moderate catch-up speed, but GDP is relatively lagging behind the Austrian average. Again, it is one-sided progress, but this time it favours HDI convergence.

Regional Statistics, Vol. 8. No. 1. 2018: 49-77; DOI: 10.15196/RS080108 
The southern provinces of Germany again form a well-performing convergence club that includes regions with 'catch-up complete' status, downward adjustment, or a high speed of convergence. The German representatives of the 'catch-up not complete' category (Trier, Schleswig-Holstein, Giessen, and Kassel) greatly differ from the same categorisation of HDI. Although most cases also show downward adjustment (compared to Austria, Kassel's position is the same in 2014 as in 2004), unlike in the case of well-being, these regions failed to reach the initial value of the reference region in 2004. In Germany, the behaviour of the central and northern regions is similar to that of the majority of eastern regions where, apart from a few exceptions, the narrowing in the development gap is $0-2 \%$ per year, typically coupled with the relative lag in social well-being. Austria is still not uniform: the GDP per capita values of several regions (Vienna, Oberösterreich, Salzburg, Tirol, and Vorarlberg) are higher than the average in 2004, but except for Vienna, there is continuous convergence without any downward adjustment. In the territory under review, the lowest speed of convergence is present in Burgenland ( $0.036 \%$ per year), located in the periphery of Austria. Compared to HDI, progress here is again onesided: the growth in social development may be attributed to state interventions. Steiermark and Kärnten also show some one-sided catch-up taking place, again in favour of HDI.

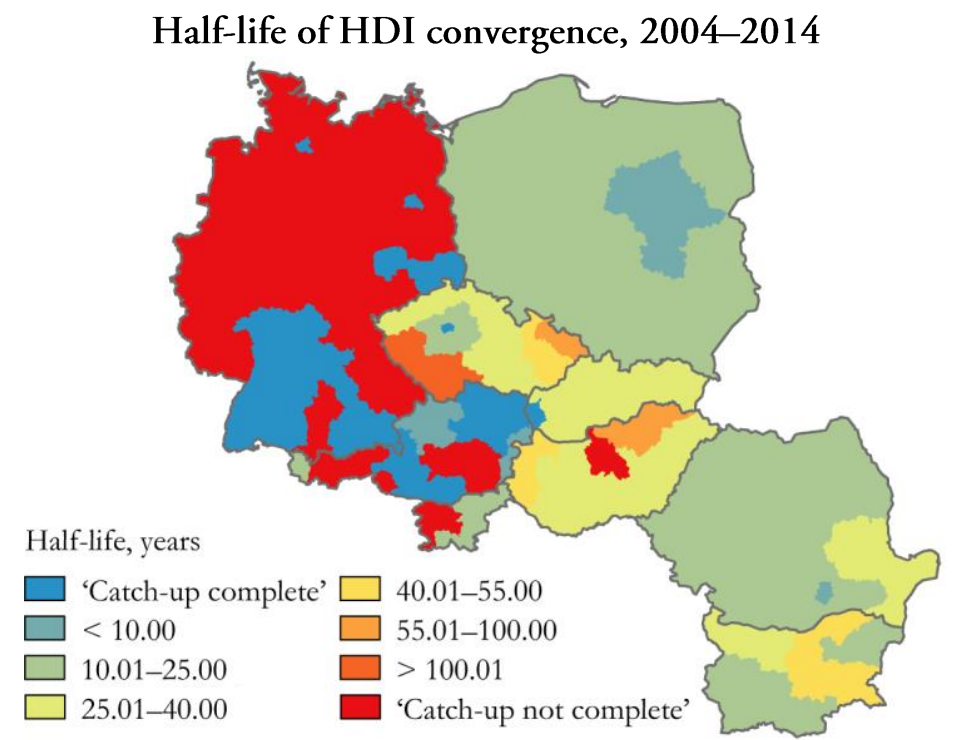

Figure 7

Due to the speed of convergence, the half-lives show here - just like for the entire CEE territory - the number of years that would be required, assuming a constant speed of convergence for the 10-year period under review, to cover half of the way to catch-up.

Regional Statistics, Vol. 8. No. 1. 2018: 49-77; DOI: 10.15196/RS080108 
In the case of HDI, the vast majority of the regions show a higher speed of convergence, which we can also see in the half-life values. We see a diverse half-life picture when we omit the non-converging or 'catch-up complete' regions from the analyses (see Figure 7). It takes 6 years for the best-performing Mazowiecki region and as many as 104 years for the Jihozápad region, which has the lowest speed of convergence, to achieve half of the full convergence.

As to the eastern capital city regions that are not lagging, Warsaw and Bucharest would catch up (assuming constant growth) with the reference level within a relatively short time (12-14 years), while the Sofia region would need almost 30 years to do the same. The short half-life of Strední Cechy, the region round Prague, is presumably attributable to the positive effects of being adjacent to the Czech capital city. When put on the map, half-life values - just like catch-up speeds - positively confirm the phenomenon of national convergence clubs, complete with the presentation of gradual progress. Except for one or two regions, Poland and Romania would achieve half of the full convergence within 10-25 years, while Slovakia would need 25-40 years to do the same. In Hungary, most regions are also expected to reach the half-way point within 25-40 years, with the relatively developed Western Transdanubia needing 43.5 years and the least developed Northern Hungary requiring 58 years. The situation is similar in the Czech Republic, where the catch-up target represents an inconceivably long period for the relatively developed Jihovychod region located in the western part of the country, while the Ostrava region (formerly involved in heavy industry) faces the same half-life as Northern Hungary (which is a not too optimistic this type of region). Except for the above region and the capital city region, the rest of the country would reach the half-way point to the full convergence target within 25-40 years. The spatial pattern of Bulgaria and Slovenia is in line with the respective speeds of convergence; only Yugoiztochen and Severen Trentsalen (Bulgaria) excel, with a half-life of 40-55 years.

When analysing the time requirement for economic catch-up (see Figure 8), we again see clusterisation and club formation - although not as clearly as for social development - in the case of continuous areas, excluding the central and western regions of Hungary, which has a half-life above 100 years (Western Transdanubia) excels at 450.5 years); we find similar features in the western part of the Czech Republic (Bohemia) and the entire territory of Slovenia. The one-sided development is most striking in Strední Cechy, with a half-life of 15.5 years for HDI and 226.9 years for GDP per capita. In Poland, the regions including the big hubs already noted are accompanied by regions such as Malopolskie (Krakow) and Pomorskie (Trójmiejski) Regions, where the relatively short half-life is the result of better initial conditions. Slovakian regions also show divergence and the East-West dichotomy is present again, however, unlike in the case of HDI, we expect a faster catch-up in western regions. Except for the capital city region, Bulgaria needs an inconceivably long time to achieve the half-way point of full convergence (Severozapaden, which has the

Regional Statistics, Vol. 8. No. 1. 2018: 49-77; DOI: 10.15196/RS080108 
lowest GDP per capita, would need 256.3 years). Burgenland and Kärnten exemplify the subtle interrelations between social and economic development. In the former region, the half-life is 6.8 years for HDI, and, assuming a constant speed of convergence for the 10-year period under review, 1,774 years for GDP per capita. The latter region shows a downward adjustment in terms of social development, while its half-life for economic convergence amounts to 465 years. The half-life varies widely in the northern part of Germany, but the provinces of the former East Germany are not necessarily worse than the West German regions. The poorest values belong to Hannover (85.2 years), Dresden (193.1 years), and Lüneburg (438.6 years).

Figure 8

Half-life of GDP per capita convergence, 2004-2014

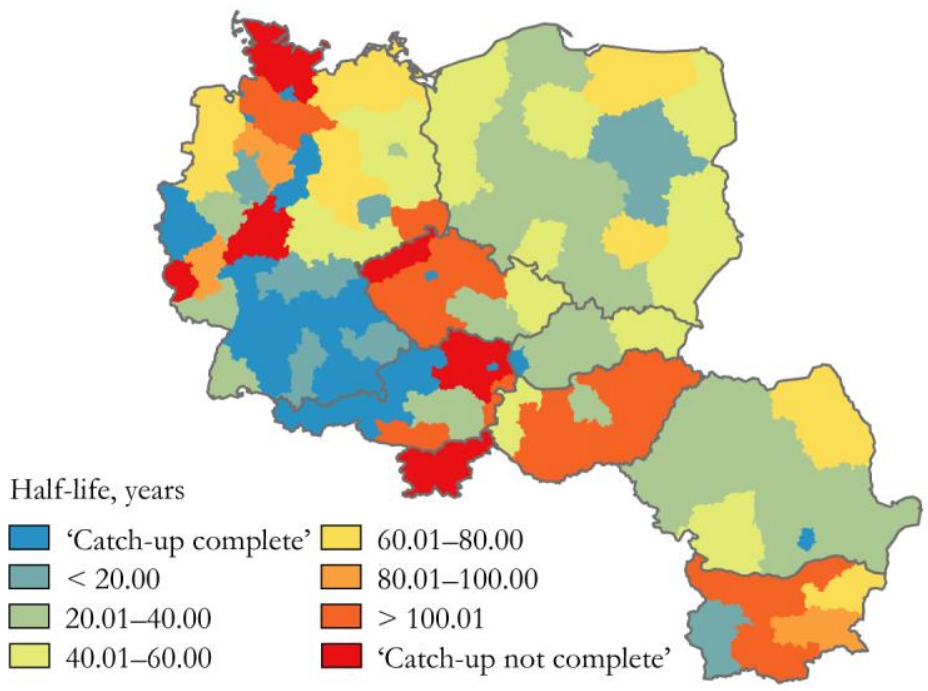

\section{Summary}

Our study discusses the convergence of economic and social (well-being) performance in the CEE NUTS 2 regions for the period of 2004-2014. We abandoned the theory of closed economies and, thus used spatial interactions and spillover effects for our study. We drafted four research questions in connection with this theme.

On the existence of strengthened convergence in CEE, there was a significant absolute convergence in the case of the economic (GDP per capita) and social development (HDI) between 2004 and 2014 in the study area. On regional economic performance, the annual speed of convergence was around $2 \%$, corresponding to the literature and conditional convergence studies, while the human development

Regional Statistics, Vol. 8. No. 1. 2018: 49-77; DOI: 10.15196/RS080108 
index was much higher, by nearly $6 \%$. So, regardless of any other explanatory factor, less developed regions tend to converge with more developed ones.

On spatiality, we can consider its dependence and the different interactions as a phenomenon that can be clearly understood in the context of the convergence and catch-up. We can consider the spatial dependence of growth rates as very strong, and the spatial divisions are heavily tied to the national boundaries, especially in the case of the HDI. Thus, similar to Rodríguez-Pose and Tselios' (2015) study on Western European regions, we can assume that in CEE regions, national institutions and culture have an effect, not only on the traditional neighbourhood relations, but also on the interactions (knowledge, technology, movement of production factors, etc.), which we can attribute to spatial similarity. We prove this in part with the regression analyses that include the variables of institutional development, though, in this case, the role of multicollinearity is significant. Therefore, both static (initial development) and dynamic data (growth rate) carry institutional characteristics (convergence clubs). Global regression models contribute significantly to the incorporation of neighbourhood characteristics. There is a significant and positive neighbourhood effect in both regressions of the developmental variables, and the growth of the two phenomena has a reliable impact on the processes in neighbouring regions. The spatial regression models explain the convergence of the area with very good efficiency. The main indices (log likelihood, Akaike information criterion) show more favourable values than in the OLS regression. We find clear differences between economic and social convergence. On the one hand, in the case of social well-being there are much more balanced relations (spatial autocorrelation, population-weighted coefficient of variation), than in the case of the GDP per capita. In addition, there is a closer correlation between initial development and the growth rate, and the annual convergence rate is considerably faster. The neighbourhood effects downplay the main indicators of convergence: the effects of the processes are more significant in the surrounding regions than it is for economic performance. The annual convergence rate falls to one-quarter of its value, and HDI has only a 12-13 percent relapse. These results highlight the two phenomena and development dimensions, which means that the redundant nature of the indicators does not replace a dynamic approach.

The global and spatial regressions provide only an average picture of the phenomenon under study, and therefore, we present the individual paths of each region in terms of Austria as the target region. The local results show the information provided by the global regressions, pointing to a number of unique features. The indicators described in the regressions (annual speed of convergence, so the narrowing in the development gap and the half-lives) are moving on a much wider scale, showing the 'catch-up complete' and 'catch-up not complete' categories. There are also significant differences in social and economic development. Similar to the regression results, social development provides a more favourable picture of catch-up.

Regional Statistics, Vol. 8. No. 1. 2018: 49-77; DOI: 10.15196/RS080108 
At the same time, which mathematical-statistical methods do not show, we find a downward adjustment, which we can call a very characteristic process, especially for HDI. Local convergence and catch-up analyses without adding spatial parameters strengthen the national character of catching up, club formation (club convergence), and the preferences of urban spaces.

Based on our results, it is important to highlight that these studies do not necessarily mean that economic and social convergence and catching up occur simultaneously. Many regions experience one-sided development (e.g. Central Hungary, Vzhodna Slovenija, Burgenland, the northern and central-German regions), which indicates the efficiency of economic performance.

Our analysis cannot be considered without criticism because we study a relatively short period that also experienced an economic crisis. At the same time, this period clearly points to the sophisticated relationships between economic and human development in the examined region.

\section{Acknowledgement}

Supported by the ÚNKP-17-4 New National Excellence Program of the Ministry of Human Capacities.

\section{REFERENCES}

Allen \& Overy (2011): CEE you there! Foreign direct investment in Central and Eastern Europe http:/ /www.allenovery.com/SiteCollectionDocuments/Foreign $\% 20$ direct $\% 20$ investment $\% 20$ in $\% 20$ Central $\% 20$ and $\% 20$ Eastern $\% 20$ Europe.PDF (downloaded: 10.11.2017.)

ANSELIN, L. (2005): Exploring Spatial Data with GeoDaTM: A Workbook Center for Spatially, Integrated Social Science, Spatial Analysis Laboratory Department of Geography, University of Illinois, Urbana-Champaign.

Balogh, P. (2017): The revival of 'Central Europe' among Hungarian political elites: Its meaning and geopolitical implications Hungarian Geographical Bulletin 66 (3): 191-202. https://doi.org/10.15201/hungeobull.66.3.1

BARro, R. J.-SAlA-I-MARTIN, X. (1990): Economic Growth and Convergence across the United States National Bureau of Economic Research. Working Paper Nr. 3419. Cambridge. http://www.nber.org/papers/w3419 (downloaded: 10.05.2017.)

BAUMOL, W. J. (1986): Productivity growth, convergence and welfare: What the long run data show? The American Economic Review 76 (5): 1072-1085.

Baumont, C.-Ertur, E.-Le Gallo, J. (2001): A Spatial Econometric Analysis of Geographic Spillovers and Growth for European Regions, 1980-1995 Research Report, Laboratoire d'analyse et de techniques économiques(LATEC). https://hal.archives-ouvertes.fr/hal-01526858/document (downloaded: 10.05.2017.)

BENEDEK, J.-KOCZISZKY, GY. (2017): Területi polarizáció és konvergencia a visegrádi országokban Magyar Tudomány 178 (3): 261-272.

Regional Statistics, Vol. 8. No. 1. 2018: 49-77; DOI: 10.15196/RS080108 
Bubbico, R. L.-Dijkstra, L. (2011): The European regional Human Development and Human Poverty Indices Regional Focus http://ec.europa.eu/regional_policy/ sources/docgener/focus/2011_02_hdev_hpov_indices.pdf (dDownloaded: 10.04.2016.)

Bucur, I. A.-STAngaciu, O. A. (2015): The European Union Convergence in Terms of Economic and Human Development Centre for European Studies, Alexandru Ioan Cuza University CES Working Papers 7 (2): 256-275.

CHAsco, C. (2013): GeoDaSpace: A resource for teaching spatial regression models https://www.researchgate.net/publication/256373609_GeoDaSpace_a_resourc e_for_teaching_spatial_regression_models (downloaded: 10.04.2016.)

CZALler, L. (2016): Agglomeráció, regionális növekedés és konvergencia Területi Statisztika 56 (3): 275-300. https://doi.org/10.15196/TS560302

DedÁK, I.-DombI, Á. (2009): Konvergencia és növekedési ütem Közgazdasági Szemle LVI. évf. 56 január(1): 19-45.

FERKELT, B.-GÁSPÁR, A. (2008): Konvergencia-vizsgálatok az Európai Unióban EU Working Papers 2008/1 http://epa.oszk.hu/00000/00026/00038/pdf/euwp_ EPA00026_2008_01_035-044.pdf (downloaded: 03.10.2016.)

GOECKE, H.-HÜTHER, M. (2016): Regional convergence in Europe Intereconomics Review of European Economic Policy 51 (3): 165-171. http:/ /dx.doi.org/10.1007/s10272-016-0595-x

GorzelaK, G. (2001): Regional development in Central Europe and European integration Informationen zur Raumentwicklung Heft (11-12): 743-749.

Gorzelak, G. (2006): Main Processes of Regional Development in Central and Eastern Europe after 1990. Regional Diversity and Local Development in Central and Eastern Europe Conference paper. 10 November 2006. Warsaw. http://www.oecd.org/dataoecd/58/41/37778478.pdf (downloaded: 20.11.2015).

HEGERTY, S. W. (2016): Regional convergence and growth clusters in Central and Eastern Europe: An examination of sectoral-level data Eastern European Business and Economics Journal 2 (2): 95-110.

Herz, B.-Voget, L. (2003): Regional Convergence in Central and Eastern Europe: Evidence from a Decade of Transition Bayreuth University Economic Discussion Paper No. 13-03., Bayreuth.

KelEjIAN, H. H.-PRUCHA, I. R. (2010): Specification and estimation of spatial autoregressive models with autoregressive and heteroskedastic disturbances Journal of Econometrics 157 (1): 53-67. https://doi.org/10.1016/j.jeconom.2009.10.025

KOCZISZKY, GY. (2013): Térökonometria alkalmazási lehetőségei a területi kutatásokban Múszaki Földtudományi Közlemények 84 (1): 111-118.

KONYA, L.-GUISAN, M. (2008): What does the Human Development Index tell us about convergence? Applied Econometrics and International Development 8 (1): 19-40.

Koтоsz, B. (2016): A konvergencia területisége és lokális szintű mérése: elméleti áttekintés Területi Statisztika 56 (2): 139-157. https://doi.org/10.15196/TS560203

Kotosz, B.-LengYeL, I. (2017): Regional Growth and Convergence of the NUTS 3 Regions of Eastern European Countries Paper presented at the 57th ERSA Congress: Social Progress for Resilient Regions, Groningen, 29 August - 1 September 2017. https://www.researchgate.net/publication/319768127_Regional_Growth_and_C

Regional Statistics, Vol. 8. No. 1. 2018: 49-77; DOI: 10.15196/RS080108 
onvergence_of_the_NUTS_3_Regions_of_Eastern_European_Countries (downloaded: 10.10 .2017$.

KŐRÖSI, I. (2015): Kelet-Közép-Európa felzárkózásának lehetôsége és kilátásai az Európai Unióban, In: KATONA, K. - KŐRÖSI, I. (eds.) Felzárkózás vagy lemaradás pp. 159-176., Pázmány Press, Budapest.

Lengyed, I.-RECHnitzer, J. (2004): Regionális gazdaságtan Dialóg Campus Kiadó, Budapest-Pécs.

MANKIW, N. G.-Romer, D.-WeIL, D. N. (1992): A contribution to the empirics of economic growth The Quarterly Journal of Economics 107 (2): 407-437. http://dx.doi.org/10.2307/2118477

Marshall, A. (1920): Principles of Economics Macmillan and Co., London.

McGillivray, M. (1991): The Human Development Index: Yet another redundant composite development indicator? World Development 19 (10): 1461-1468. http://dx.doi.org/10.1016/0305-750X(91)90088-Y

OBLATH, G. (2014): Gazdasági átalakulás, nekilendülés és elakadás. Magyarország makrogazdasági konvergenciája az Európai Unió fejlett térségéhez az 1990-es évek elejétől 2013-ig In: Kolosi, T.-Tóth, I. Gy. (eds.) Társadalmi riport pp. 21-50, TÁRKI, Budapest.

OBLATH, G.-SzÖRFI, B. (2008): Makrogazdasági konvergencia az EU új tagországaiban In: KOLOSI, T.-TóTH, I. GY. (eds.): Társadalmi riport pp. 204-225., TÁRKI, Budapest.

PAas, T.-KuUsK, A.-SCHLITTE F.-VÕRK, A. (2007): Econometric Analysis of Income Convergence in Selected EU Countries and Their NUTS 3 Level Regions The University of Tartu Faculty of Economics and Business Administration Working Paper No. 60-2007, Tartu. http://dx.doi.org/10.2139/ssrn.1078863

QUAH, D. T. (1993): Galton's fallacy and test of the convergence hypothesis Scandinavian Journal of Economics 95 (4): 427-443. https://doi.org/10.2307/3440905

RECHNiTZER, J.-SMAHÓ, M. (2011): Területi politika Akadémiai kiadó, Budapest.

REY, S. J.-MONTOURI, B. D. (1999): US regional income convergence: A spatial economic perspective Regional Studies 33 (2): 143-156. https://doi.org/10.1080/ 00343409950122945

Rodríguez-Pose, A.-Tselios, V. (2015): Toward inclusive growth: Is there regional convergence in social welfare? International Regional Science Review 38 (1): 30-60. https://doi.org/10.1177/0160017613505201

ROMER, P. M. (1986): Increasing returns and long-run growth Journal of Political Economy 94 (5): 1002-10327. https://doi.org/10.1086/261420

SME,TKOWSKI, M.-WÓJCIK, P. (2012): Regional convergence in Central and Eastern European countries: A multidimensional approach European Planning Studies 20 (6): 923-939. https://doi.org/10.1080/09654313.2012.673560

$\mathrm{SME}_{\mathrm{s}}$ TKOWSKI, M. (2015): Spatial patterns of regional economic development in Central and Eastern European countries Geographia Polonica 88 (4): 539-555. https://doi.org/10.7163/GPol.0033

Solow, R. (1956): A contribution to the theory of economic growth Quarterly Journal of Economics 70 (1): 65-94.

Stiglitz, J. E.-SEN, A.-Fitoussi, J-P. (2009): Report by the Commission on the Measurement of Economic Performance and Social Progress http://ec.europa.eu/

Regional Statistics, Vol. 8. No. 1. 2018: 49-77; DOI: 10.15196/RS080108 
eurostat/documents/118025/118123/Fitoussi+Commission+report (downloaded: 20.11.2015)

TAGAI, G. (2004): Kelet-Közép-Európa gazdasági és népességi potenciáltere Műhelytanulmányok 2004/26. MTA Közgazdaságtudományi Intézet, Budapest.

TAGAI, G. (2011): Térkapcsolati modellek a regionális kutatásokban PhD-értekezés. (Doctoral dissertation.) Eötvös Loránd Tudományegyetem Természettudományi Kar, Budapest.

TóTH, G. (2014): Térinformatika a gyakorlatban közgazdászoknak Miskolci Egyetem, Miskolc. http://gtk.uni-miskolc.hu/files/6405/Terinfo.pdf (downloaded: 11.10.2016.)

TótH, Zs. (2016): Konvergenciavizsgálatok az Európai Unióban - A visegrádi négyek felzárkózásának értékelése kiterjesztett konvergencia-index alkalmazásával PhDértekezés. (Doctoral dissertation.) Pannon Egyetem Gazdálkodás- és Szervezéstudományok Doktori Iskola, Keszthely.

TrabOld-NÜBler, H. (1991): The Human Development Index - A new development indicator? Intereconomics 26 (5): 236-243. https:// doi.org/10.1007/BF02928996

Treaty Establishing the European Community (1957): http://www.hri.org/docs/Rome57/

UMANTSIV, I.-IsHCHENKO, O. (2017): Banking sector and economy of CEE countries: Development features and correlation Journal of Settlements and Spatial Planning 8 (1): 59-70. http://dx.doi.org/10.24193/05JSSP012017

UNDP (2010): Human Development Report 2010, 20th Anniversary Edition. The Real Wealth of Nations: Pathways to Human Development Palgrave Macmillan, New York.

UNDP (2016): Human Development Report 2016 Human Development for Everyone http://hdr.undp.org/sites/default/files/2016_human_development_report.pdf (downloaded: 12.05.2017.)

VARGA, A (2009) Térszerkezet és gazdasági növekedés Akadémiai Kiadó, Budapest.

VÁRY, A. (2017): Számít-e a földrajzi elhelyezkedés? A nyugat-európai régiók fejlettségének térökonometriai vizsgálata Közgazdasági Szemle LXIV. évf. 64 március(3): 238-266. http://dx.doi.org/10.18414/KSZ.2017.3.238

VIEgas, M.-Antunes, M. (2013): Convergence in the Spanish and Portuguese NUTS 3 regions: An exploratory spatial approach Intereconomics 48 (1): 59-66. https://doi.org/10.1007/s10272-013-0445-z

VOJINOVIĆ, B.-ACHARYA, S.-PRÓCHNIAK, M. (2009): Convergence analysis among the ten European transition economies Hitotsubashi Journal of Economics 50 (2): 1735. http://doi.org/10.15057/18049

YANG, F.-PAN, S.-YAO, X. (2016): Regional convergence and sustainable development in China Sustainability 8 (2): 1-15. https://doi.org/10.3390/su8020121

ZEGHNI, S.-FABRY, N. (2008): Building institutions for growth and human development: An economic perspective applied to the transitional countries of Europe and CIS MPRA Paper No. 9171 https://mpra.ub.uni-muenchen.de/9171/1/ MPRA_paper_9171.pdf (downloaded: 07.11.2017.)

Regional Statistics, Vol. 8. No. 1. 2018: 49-77; DOI: 10.15196/RS080108 